\title{
A Study of DI Diesel Engine using Mahua Biodiesel and Petro-Diesel
}

\author{
Dr. C. Solaimuthu*, P. Vetrivel and M. R. Subbarayan \\ ${ }^{I}$ Professor cum Director (Research), Department of Mechanical Engineering, Er. Perumal Manimekalai \\ College of Engineering, Hosur - 635 117, Tamil Nadu, India \\ ${ }^{2}$ Assistant Professor, Department of Mechanical Engineering, Jayam College of Engineering and Technology, \\ Dharmapuri - 636813, Tamil Nadu, India \\ ${ }^{3}$ Associate Professor, Department of Mechanical Engineering, Jayam College of Engineering and Technology, \\ Dharmapuri - 636813, Tamil Nadu, India
}

\begin{abstract}
The engine emission characteristics of Mahua biodiesel (Mahua oil Methyl Ester) and petro-diesel are presented. The thermo-physical properties of all the fuel blends have been measured and presented. The engine tests are conducted on a 4Stroke Tangentially Vertical (TV) single cylinder kirloskar $1500 \mathrm{rpm}$ water cooled direct injection diesel engine with eddy current dynamometer at different static injection timings of $22^{\circ}, 23^{\circ}$ (standard) and $24^{\circ} \mathrm{bTDC}$ under standard nozzle opening pressure of 240 bar maintained as constant throughout the experiment under steady state conditions at full load condition of the engine. From the test results, it could be observed that the lower static injection timing (22 ${ }^{\circ} \mathrm{bTDC}$ ) for B0 fuel and B100 fuel give lower Carbon Monoxide, Smoke Density and Oxides of Nitrogen in the case of emissions.
\end{abstract}

Keywords: - Petro-Diesel; Biodiesel; Static Injection Timings; Engine Emissions

\section{INTRODUCTION}

The diesel engine sector forms a vital part of transportation systems in all the developed and developing countries of the world. However, diesel engine exhaust emissions are a major contributor to environment pollution. The conventional fossil fuel (diesel) used in diesel engines contains higher amounts of aromatics and sulphur, which cause environment pollution. As an example, higher amount of particulate matter $(\mathrm{PM})$, unburned hydrocarbon $(\mathrm{HC})$, oxides of nitrogen $\left(\mathrm{NO}_{\mathrm{x}}\right)$, carbon dioxide $\left(\mathrm{CO}_{2}\right)$ and oxides of sulphur $\left(\mathrm{SO}_{\mathrm{x}}\right)$ are produced from fossil-fuelled diesel engine exhaust emissions. Moreover, $\mathrm{NO}_{\mathrm{x}}$ and $\mathrm{CO}_{2}$ are the green house gases and $\mathrm{SO}_{\mathrm{x}}$ causes acid rain. Bio-fuel contains less aromatic content and is practically sulphur-free, and produces complete combustion due to its oxygen content in comparison with conventional diesel fuel. Secondly, the environmental benefit is another motivation factor due to a lesser green house effect, less local air pollution, less contamination for water and soil and a reduced health risk. There are different types of Biodiesels are available such as Cottonseed, Soybean, Sunflower, Soyabean, Mahua, Linseed, Pongamia, Jatropha, etc., From the previous studies, it could be observed that most of the studies are mainly related to the emission characteristics of diesel engine using biodiesel as fuel. In this paper an analysis of 4S TV 1 DI with static injection timings of $22^{\circ}, 23^{\circ}$ (standard) and $24^{\circ}$ bTDC and with a constant nozzle opening pressure of 240 bar at full load condition of the diesel engine with eddy current dynamometer using $\mathrm{B} 0$ and $\mathrm{B} 100$ as fuel is presented.

II. EXPERIMENTAL SETUP AND PROCEDURE

Experiments have been conducted on a 4 stroke, kirloskar, TV 1 direct injection diesel engine developing power output of $5.2 \mathrm{~kW}$ at $1500 \mathrm{rpm}$ connected with water cooled eddy current dynamometer. The schematic diagram of the engine setup is shown in Fig. 1. The static injection timings of $22^{\circ}, 23^{\circ}$ (standard) and $24^{\circ} \mathrm{bTDC}$ and the standard nozzle opening pressure of $240 \mathrm{bar}$ are used for the entire experiments at full load condition of the engine. AVL 444 di-gas analyzer is used for the measurement of exhaust emission of $\mathrm{CO}, \mathrm{CO}_{2}$, $\mathrm{NO}_{\mathrm{x}}$. Smoke level is measured using standard AVL 437 smoke meter. All the experimental readings have been taken under steady state conditions of the engine. 


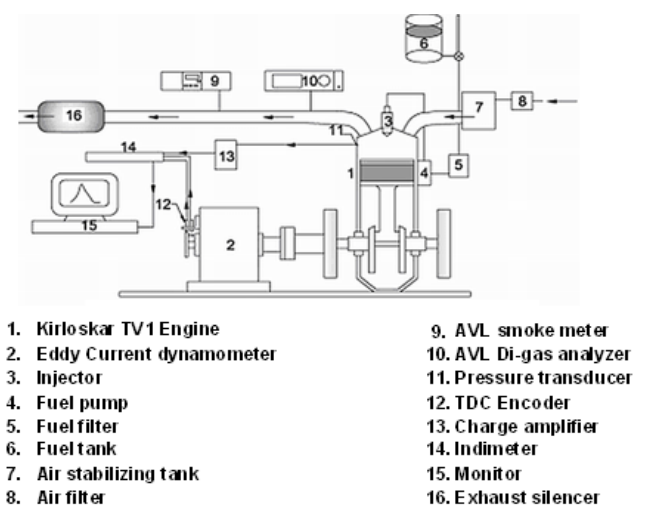

Figure 1: Schematic Diagram of the Engine Setup

Table 1: Properties of Mahua Biodiesel and Petro-Diesel

\begin{tabular}{|l|l|l|l|}
\hline S. No & \multicolumn{1}{|c|}{ Name of the Properties } & \multicolumn{1}{c|}{ B0 } & \multicolumn{1}{c|}{ B100 } \\
\hline 1 & Kinematic Viscosity at $40^{\circ} \mathrm{C}$ in cSt & 2.6 & 6.04 \\
\hline 2 & Gross Calorific Value in $\mathrm{kJ} / \mathrm{kg}$ & 45,596 & 41,819 \\
\hline 3 & Flash Point in ${ }^{\circ} \mathrm{C}$ & 65 & 170 \\
\hline 4 & Fire Point in ${ }^{\circ} \mathrm{C}$ & 70 & 183 \\
\hline 7 & Specific Gravity & 0.82 & 0.88 \\
\hline
\end{tabular}

From Tab. 1, it is clear that specific gravity, kinematic viscosity, flash point and fire point increases as the biodiesel content in the biodiesel-diesel blends increases. Especially, the significant increase in the fire point shows that the volatility of the mixture having increased, biodiesel content will decrease. It is also observed that the flash point and fire point of biodiesel increase. Therefore B100 is very easy to store and safe for transportation as compared with B0 (pure diesel). The gross calorific value decreases as the biodiesel in the mixture increases.

\subsection{Carbon di-oxide}

\section{RESULTS AND DISCUSSION}

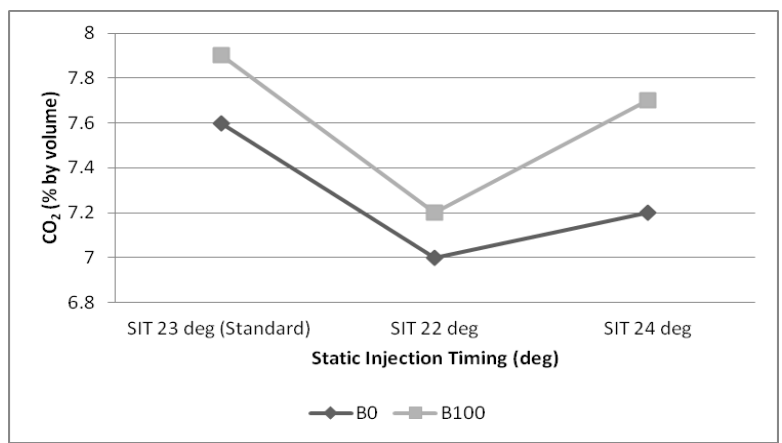

Figure 2: Carbon-di-oxide vs SIT

Figure 2 shows variation of Carbon di-oxide with respect to static injection timings of $22^{\circ}, 23^{\circ}$ (standard) and $24^{\circ}$ bTDC. From the test results, it could be stated that the $22^{\circ}$ bTDC of static injection timing gives lowest $\mathrm{CO}_{2}$ (\% by volume) as compared to all other static injection timings. The percentage reduction of $\mathrm{CO}_{2}$ for injection timing of $22^{\circ}$ for $\mathrm{B} 0$ and $\mathrm{B} 100$ is 7.82 and 8.76 respectively as compared with standard injection timing of $23^{\circ}$ bTDC. Among fuels, the $\mathrm{B} 100$ gives highest $\mathrm{CO}_{2}$ of 8.86 in terms of percentage reduction of $\mathrm{CO}_{2}$ at full load condition. This may be due to oxygen (\% by volume) of $\mathrm{B} 100$ is comparatively lower than that of all other blends. Therefore, there may be a possibility of getting better combustion with lower emissions. 


\subsection{Carbon monoxide}

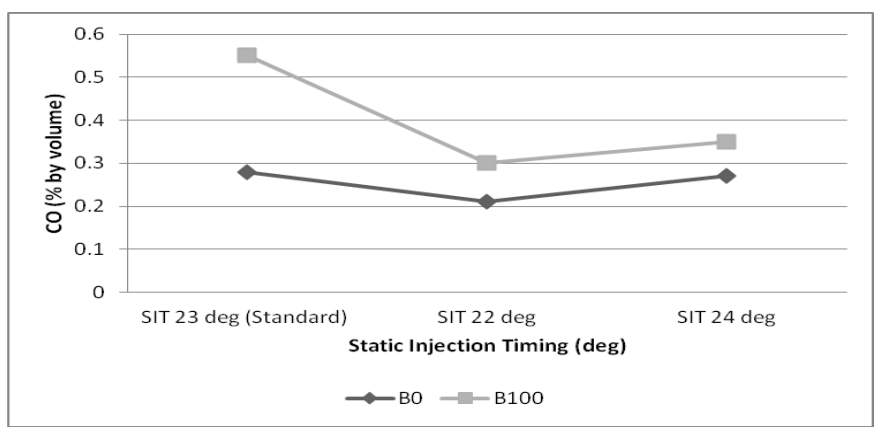

Figure 3: Carbon monoxide vs SIT

The variation of Carbon monoxide with respect to static injection timings of $22^{\circ}, 23^{\circ}$ (standard) and $24^{\circ}$ bTDC is shown in figure 3. From the graph results, it could be observed that the $22^{\circ}$ bTDC of static injection timing gives lowest $\mathrm{CO}$ as compared to all other static injection timings for all blends of fuel. The percentage reduction in $\mathrm{CO}$ (\% by volume) for static injection timing of $22^{\circ}$ bTDC for B0 and B100 is 25.05 and 44.78 respectively as compared with standard static injection timing of $23^{\circ} \mathrm{bTDC}$. Among the blends, the $\mathrm{B} 100$ gives highest percentage of reduction in $\mathrm{CO}$ of 44.78 at full load condition of the engine.

\subsection{Smoke Density}

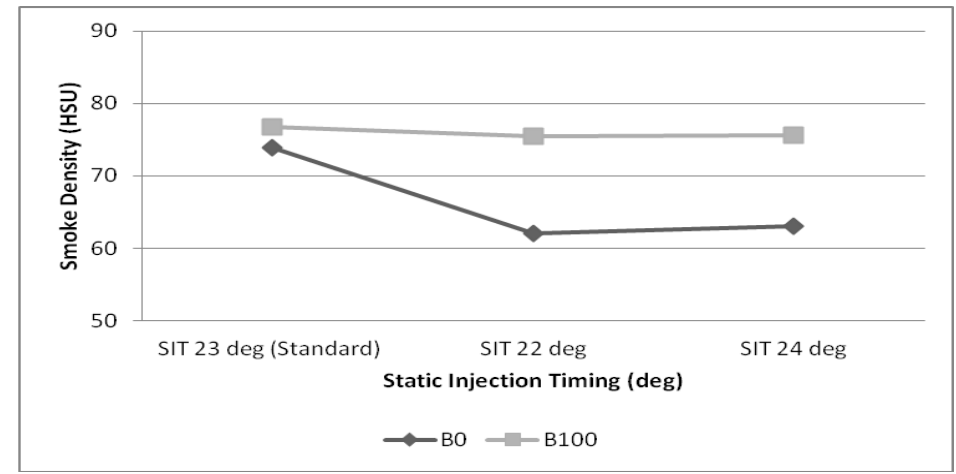

Figure 4: Smoke Density vs SIT

Figure 4 shows variation of Smoke Density with respect to static injection timings of $22^{\circ}, 23^{\circ}$ (standard), and $24^{\circ}$ bTDC. From the test results, it could be observed that the $22^{\circ}$ bTDC of static injection timing gives lowest Smoke Density (HSU) as compared to all other static injection timings. The percentage reduction in Smoke Density for static injection timing of $22^{\circ}$ bTDC for B0 and B100 is 15.67 and 1.56 respectively as compared with standard static injection timing of $23^{\circ} \mathrm{bTDC}$. Among the blends, the B0 gives highest Smoke Density of 15.67 in terms of percentage reduction in Smoke Density at full load condition of the engine.

\subsection{Hydrocarbon}

The variation of Hydrocarbon with respect to static injection timings of $22^{\circ}, 23^{\circ}$ (standard), and $24^{\circ}$ bTDC is shown in figure 5. From the test results, it could be stated that the $22^{\circ}$ bTDC of static injection timing gives lowest hydrocarbon as compared to all other timings for both fuels.

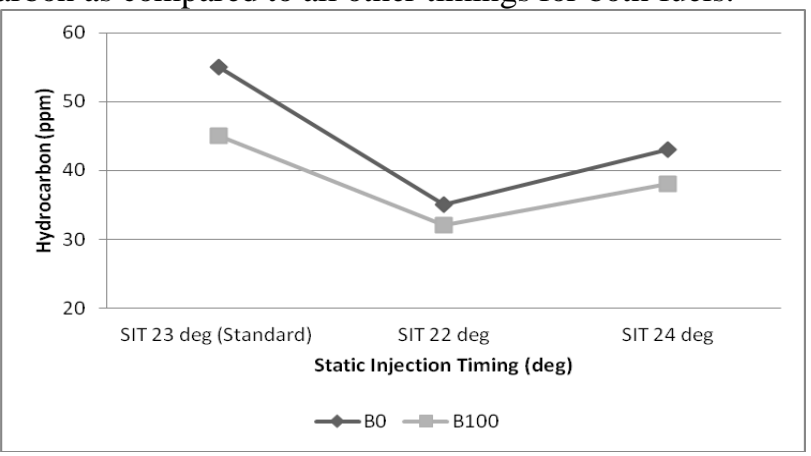

Figure 5: Hydrocarbon vs SIT 
The percentage of reduction in hydrocarbon (ppm) for static injection timing of $22^{\circ}$ for $\mathrm{B} 0$ and B100 is 35.56 and 26.78 respectively as compared with static injection timing of $23^{\circ}$ bTDC. Among the blends, the B0 gives highest hydrocarbon of 35.56 in terms of percentage of reduction in hydrocarbon at full load condition. This variation may be due to presence of oxygen in the fuel, which promotes the combustion process.

\subsection{Oxides of Nitrogen}

Figure 6 shows variation of Oxides of Nitrogen $\left(\mathrm{NO}_{\mathrm{x}}\right)$ with respect to static injection timings of $22^{\circ}$, $23^{\circ}$ (standard) and $24^{\circ}$ bTDC. From the test results, it could be seen that the $22^{\circ}$ bTDC of static injection timing gives lowest $\mathrm{NO}_{\mathrm{x}}(\mathrm{ppm})$ as compared to all other SITs for both fuels. The percentage reduction in $\mathrm{NO}_{\mathrm{x}}$ for static injection timing of $22^{\circ}$ bTDC for B0 and B100 is 22.45 and 14.45 respectively as compared with standard static injection timing of $23^{\circ}$ bTDC. Among the fuels, the $\mathrm{B} 0$ gives highest $\mathrm{NO}_{\mathrm{x}}$ of 22.45 in terms of percentage reduction in $\mathrm{NO}_{\mathrm{x}}$ at full load condition. There are two parameters which influence the engine $\mathrm{NO}_{\mathrm{x}}$ emission, stoichiometric air fuel ratio and the flame temperature.

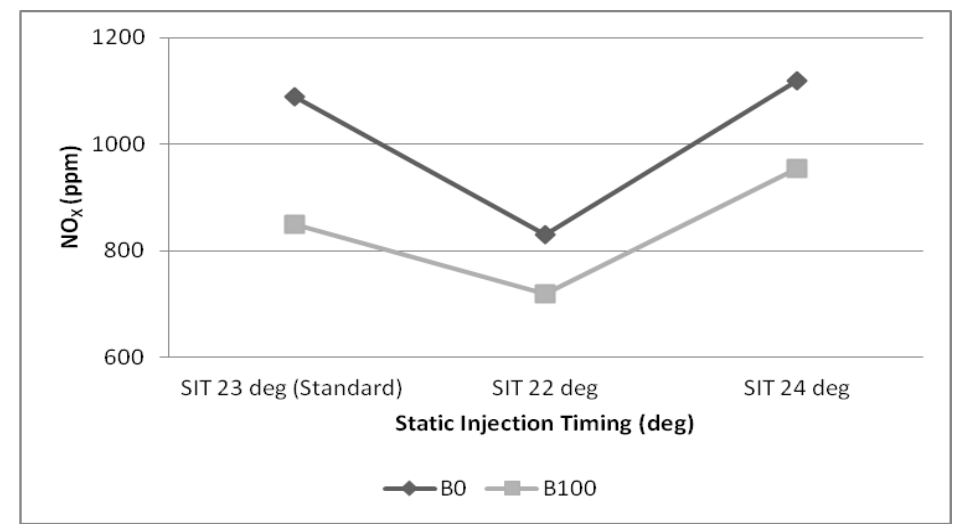

Figure 6: Oxides of Nitrogen vs SIT

IV. CONCLUSIONS

From these readings, it could be concluded that the B100 safely used as an alternative fuel for operating four stroke tangentially vertical single cylinder kirloskar direct injection water cooled constant speed diesel engine with static injection timing of $22^{\circ}$ bTDC and nozzle opening pressure of 240 bar.

\section{REFERENCES}

[1] A S Ramadhas, S. Jayaraj and C. Muraleedharan, Use of vegetable oils as IC engine fuels: A review, Renewable Energy, 29, 2003, 27-742.

[2] P Srinivasa Rao and K.V Goplalakrishna. Esterified oils as fuels in diesel engine, $11^{\text {th }}$ National Conference on IC Engines, IIT Madras, 1983, India.

[3] Canakci and Vam Geroen, 2003, A pilot plant to produce biodiesel form high free fatty acid feedstock, American society of agricultural engineers, 46 (4), 2003, 945-954.

[4] M A Fangrui and A. Milford, Hanna biodiesel production: a review, Bioresource Technology, 70, 1993, 1-15.

[5] Suresh Kumar, A.K. Gupta and S.N. Naik, Conversion of non-edible oil into biodiesel, Journal of Scientific and Industrial Research, 62, 2003, 124-132.

[6] M Martin and D. Prithviraj, Performance of Pre-heated Cottonseed Oil and Diesel Fuel Blends in a Compression Ignition Engine, Jordan Journal of Mechanical \& Industrial Engineering, 5 (3), 2011, 235 $-240$.

[7] H Raheman and S.V. Ghadge, Performance of compression ignition engine with Mahua (Madhuca Indica) biodiesel, Fuel, 86, 2007, 2568-2573.

[8] J B Heywood, Internal Combustion Engine Fundamentals, McGraw Hill, New York, 1988, USA. 